Saudi Journal of Business and Management Studies Abbreviated Key Title: Saudi J Bus Manag Stud ISSN 2415-6663 (Print) |ISSN 2415-6671 (Online) Scholars Middle East Publishers, Dubai, United Arab Emirates Journal homepage: http://scholarsmepub.com/sjbms/

Original Research Article

\title{
Implication of Internal Audit Quality, Job Satisfaction, Asimetric Information and Good Governance on Accounting Fraudulent Tendency
}

\author{
Rona Tumiur Mauli Caroline Simorangkir ${ }^{1 *}$, Garin Prastiwi Solihati ${ }^{1}$, Molina $^{2}$, Bambang Subiyanto ${ }^{2}$ \\ ${ }^{1}$ Mercu Buana University, Jl. Meruya Selatan No.1, RT.4/RW.1, Meruya Sel., Kec. Kembangan, Kota Jakarta Barat, Daerah Khusus Ibukota Jakarta \\ 11650 , Indonesia \\ ${ }^{2}$ National University Bangladesh, Dhaka - Mymensingh Hwy, Gazipur 1704, Bangladesh
}

\begin{abstract}
DOI: $10.36348 /$ SJBMS.2019.v04i12.003
| Received: 08.11.2019 | Accepted: 21.11.2019 | Published: 11.12.2019
\end{abstract}

*Corresponding author: Rona Tumiur Mauli Carolin Simorangkir

\section{Abstract}

The accounting fraudulent tendency has developed in various countries, including in Indonesia with the corruption perception index in 2017 ranked 96 out of 180 countries in the world. This study aims to examine whether the influence of internal audit quality, job satisfaction, Asimetric Information, Good Corporate Governance towards accounting fraudulent tendency. The population in this study consisted of bank employees at BTN KC, BNI KC, BRI Syariah KC and BCA KCP in Tangerang. The sampling method used is simple random sampling. The data type used is primary data obtained from the results of the questionnaire answers by the sample. Smart Partial Least Square (SmartPLS) path modeling method is used as an analysis method. The results of this study indicate that internal audit quality has a negative influence on accounting fraudulent tendency. The relationship between the Internal Audit Quality variable and Accounting Fraudulent Tendency is equal to -0.353 with a T-statistic value of 2.827> 1.98, Ho is rejected and Ha is accepted. Job satisfaction has a negative influence on accounting fraudulent tendency. The relationship between Job Satisfaction variable and Accounting Fraudulent Tendency is equal to -0.519 with a T-statistic value of 3.489> 1.98, Ho is rejected and $\mathrm{Ha}$ is accepted. Asimetric Information has no influence on accounting fraudulent tendency. the relationship between Asymmetric Information variable and Accounting Fraudulent Tendency is equal to 0.163 with a Tstatistic value of $1.477<1.98$, Ho is accepted and Ha is rejected.

Good Corporate Governance has no influence on accounting fraudulent tendency. The relationship between Good Governance variables and Accounting Fraudulent Tendency is equal to 0.040 with a T-statistic value of $0.468<1.98$, Ho is accepted and Ha is rejected.

Keywords: internal audit quality, job satisfaction, asimetric information, good corporate governance, accounting fraudulent tendency..

Copyright @ 2019: This is an open-access article distributed under the terms of the Creative Commons Attribution license which permits unrestricted use, distribution, and reproduction in any medium for non-commercial use (NonCommercial, or CC-BY-NC) provided the original author and source are credited.

\section{INTRODUCTION}

Accounting fraud has attracted a lot of media attention and has become a trending topic and important in the eyes of both internal and external parties. The accounting fraudulent tendency has developed in various countries, including in Indonesia with the corruption perception index in 2017 ranked 96 out of 180 countries in the world (https://www.transparency.org on February 15 2018) [1]. Indonesia has experienced a decline in rank, where in 2016 Indonesia was ranked 90th out of 180 countries in the world (https://www.transparency.org on 25
January 2017) [2]. Evidence of accounting fraud in Indonesia includes the liquidation of several banks, embezzlement of cash receipts, theft of company assets, price mark-ups, informal transactions, and so on.

Internal audit quality is still in the spotlight because internal auditors are in the organization / company and get benefits by the company so that independence and objectivity, professional ability, scope of work, and the implementation of partial audits of internal auditors are sometimes still in doubt. Many audit findings were not detected by the Internal Audit 
Unit (SPI) as an internal audit, but were discovered by the Financial Supervisory Agency (BPK) as an external audit. This shows that the internal audit quality is relatively poor. The case of fraud committed by one of the bank's employees was a case at Bank Central Asia (BCA) in December 2011 with a fraud case in terms of passing a fictitious loan application made by a BCA employee as a Senior Account Officer with the task of analyzing the credit submitted by the customer with cooperating with a residential property broker, the case is a case of mark up disbursing credit loans with fictitious and fictitious documents as an effort to disburse funds by pledging fake assets to the bank of 25 billion rupiah through intermediaries of bank employees who do not carry out inspection procedures accordingly standard rules that apply to approve the fictitious credit application (http://beritasatu.com, 3/4/2014).

Job satisfaction is one of the important factors to determine employee performance in an agency or company. According to Zainal et al., [3] states that job satisfaction is an assessment of workers about how far their overall work satisfies their needs. organizational needs are usually associated with money, because money can meet a person's life needs to buy clothing, food, and shelter.

Suginam [4] examined the influence of the role of internal audit on fraud prevention. The results of the study prove that the internal audit of the company has a large role in the company to control and evaluate the activities of the company, especially in the prevention of fraud. Supported by research conducted by Abdi Saputra [5] regarding the influence of internal control systems, internal audit and the application of good corporate governance to banking fraud. The results of the study prove that the influence of the internal control system, internal audit and the application of good corporate governance have a significant negative effect on banking fraud. Another study conducted by Parasmita Ayu Putri [6] on the effect of the effectiveness of internal control and job satisfaction on the tendency of accounting fraudulent tendency revealed that the effectiveness of internal control and job satisfaction had a significant negative effect on accounting fraudulent tendency. Organizational managers know more internal information than the users of financial statements, so these conditions can make certain managers more free or have the opportunity to manipulate the financial statements presented due to the ignorance of external users about the numbers of actual financial statements [7].

Agency theory is the basis of the theory underlying the company's business practices that have been used so far. The theory is coming from the synergy of economic theory, decision theory, sociology, and organizational theory. In this study, researchers used agency theory proposed by Jensen and Meckling [8] which states that agency theory can explain the relationship that occurs between owners and shareholders (principal) with management (agents). In the case of accounting fraud, one form of conflict underlying the occurrence of fraud is due to differences in interests between the principal and the agent running the company. This theory was put forward by Jack Bologna, which was also disclosed in the 1999 National Corruption Eradication Strategy book by BPKP [9]. There are four driving factors for someone cheating, known as the Gone theory, namely: Greed (greed), Opportunity (opportunity), Need (need), and Exposure (disclosure).

\section{HYPOTHESIS}

According to J. Supranto [20] the hypothesis is a proposed condition or principle that is assumed to be true and perhaps without the conviction to be pulled a logical consequence and in this way then tested the truth by using the facts (data) that exist quantitatively, the hypothesis can also mean the statement of a parameter that is temporarily considered correct.

This study examines whether there is an influence between internal audit quality, job satisfaction, asimetric information, good corporate governance towards accounting fraudulent tendency. Internal audit is an examination conducted by the company's internal audit section, on the company's financial statements and accounting records as well as compliance with predetermined top management policies and adherence to government regulations and the provisions of applicable professional [10]. This research is supported by Suginam Ginam [4] in his research stating that internal audit companies have a large role in the company to control and evaluate the activities of the company's activities, especially in the prevention of fraud. Supported also by Abdi Saputra [5] the results of the study prove that internal audit has a significant negative effect on banking fraud. According to Mappanyukki [11] states that the control environment, risk assessment, control activities, information and communication and joint monitoring together have a positive and significant effect on prevention of fraud.

\section{$\mathrm{H}_{1}$ : Internal Audit Quality to Accounting Fraudulent Tendency}

Job satisfaction is a feeling that arises in an employee, if the work done is sufficient when compared to the standards of work that have been established [12]. The results of the research conducted by Putri [6] revealed that job satisfaction had a significant negative effect on accounting fraud tendencies. Company should create job satisfaction among the employee, such as giving the incentive to employee. According to Surjandari [13] "making evaluation in Performance Incentive not only based to the level of officer also take into account the competence, seniority, honesty, fairness distribution and the performance it self." 


\section{H2: Job Satisfaction to Accounting Fraudulent Tendency}

Asymmetry Information is a situation where there is a misalignment of information between parties who have or provide information with parties who need information [14]. Organizational managers are more aware of internal information compared to users of financial statements, so that these conditions can make certain managers more flexible or have the opportunity to manipulate financial statements presented due to ignorance of external users about the actual financial statements [7].

\section{H3: Asymmetry Information to Accounting Fraudulent Tendency}

The Forum for Corporate Governance in Indonesia (FCGI) defines Good Governance as a set of rules that establish relations between government, employees and other internal and external stakeholders in relation to their rights and obligations, or can be said as a system that directs and controls the company or entity [15]. The higher the effectiveness of the internal control system, the lower the fraud that occurs.

\section{H4: Good Governance to Accounting Fraudulent Tendency}

\section{RESEARCH METHODS}

The variables tested through questionnaires are variables internal audit quality, job satisfaction, asimetric information, good corporate governance with the measurement method used is likert scale. Researchers will use the concept of Structural Equation Modeling (SEM) for this study. Structural Equation Modeling (SEM) is a multivariate technique that combines aspects of factor analysis and multiple regression analysis that allows researchers to simulate a series of dependent relationships between measured variables and latent constructs as well as between latent constructs [16].

The influence of a latent variable that influences the relationship between an independent latent variable and dependent latent variable is called Moderated Structural Equation Modeling [17].

This research is supported by Smart PLS 3.0 program as a means of testing statistical data to determine the level of significance of the relationship of variables studied where:

- The sample does not have to be large

- Does not require very strict assumptions

- Application method is emphasized to predict the response variable rather than the shape of the model.

\section{DATA SOURCES}

The population in this study were BTN KC, BNI KC, BRI Syariah KCP and BCA BCA Branch $\mathrm{KCP}$, Banten Province. The sampling technique used in this study is the Purposive Sampling technique. The distribution of the questionnaire was carried out directly by delivering to 4 banks a total of 110 questionnaires. A summary of the number of shipments and returns of questionnaires in this study can be seen in Table-1.

Table-1: Questionnaire Distribution

\begin{tabular}{|r|r|r|r|}
\hline No & Agency & Distributed questionnaire & Returning questionnaire \\
\hline 1. & BNI & 30 & 21 \\
\hline 2. & BRIS & 35 & 33 \\
\hline 3. & BTN & 30 & 20 \\
\hline 4. & BCA & 15 & 14 \\
\hline
\end{tabular}

Sumber: Data primer

Analisis data yang digunakan adalah Partial Least Square (PLS) yang terdiri dari Outer model
(Model Measurement) dan Inner Model (Model Structural) 
Table-2: Research Definition and Operations

\begin{tabular}{|c|c|c|c|}
\hline & Variable & Indicator & $\begin{array}{l}\text { Measurement } \\
\text { Scale }\end{array}$ \\
\hline $\mathbf{X}$ & \multicolumn{3}{|c|}{ Dependent Variable } \\
\hline $\mathrm{X} 1$ & $\begin{array}{l}\text { Audit Internal } \\
\text { Quality }\end{array}$ & $\begin{array}{l}\text { a. quality of audit work } \\
\text { b. Organizational independence } \\
\text { c. Careers and progress } \\
\text { d. Top management Support }\end{array}$ & $\begin{array}{l}\text { Ordinal Scale } \\
\text { Measured by } 5- \\
\text { point Likert scale }\end{array}$ \\
\hline $\mathrm{X} 2$ & $\begin{array}{l}\text { Job } \\
\text { Satisfaction }\end{array}$ & $\begin{array}{l}\text { a. The work itself } \\
\text { b. Salary } \\
\text { c. Promotion opportunity } \\
\text { d. Boss } \\
\text { e. Co-workers }\end{array}$ & $\begin{array}{l}\text { Ordinal Scale } \\
\text { Measured by } 5- \\
\text { point Likert scale }\end{array}$ \\
\hline X3 & $\begin{array}{l}\text { Asimetris } \\
\text { Information }\end{array}$ & $\begin{array}{l}\text { a. Jobs in accounting, only internal parties that know all the } \\
\text { information relating to company transactions and have } \\
\text { financial impact. } \\
\text { b. Only an internal party agency understands the entire } \\
\text { relationship between financial transaction data and the process } \\
\text { of preparing financial statements. } \\
\text { c. Only internal parties that know and understand the contents } \\
\text { and numbers in the financial statements that have been } \\
\text { completed } \\
\text { d. Only internal parties that understand financial reporting. } \\
\text { e. Only internal parties of agencies know the factors that } \\
\text { influence financial reporting activities. } \\
\text { f. Only internal parties of agencies that know the actual content } \\
\text { and numbers and financial statements prepared. }\end{array}$ & $\begin{array}{l}\text { Ordinal Scale } \\
\text { Measured by } 5- \\
\text { point Likert scale }\end{array}$ \\
\hline $\mathrm{X} 4$ & $\begin{array}{l}\text { Good } \\
\text { Governance }\end{array}$ & $\begin{array}{l}\text { a. Each field and employee has the ability according to their } \\
\text { duties, responsibilities, and respective roles } \\
\text { b. Each field adheres to the principles of caution in carrying out } \\
\text { their respective duties and functions. } \\
\text { c. Providing opportunities for parties who have an interest in } \\
\text { providing input and opinions for the interests of the agency } \\
\text { d. Compliance with agency regulations. } \\
\text { e. In carrying out their duties and responsibilities, always adhere } \\
\text { to agreed ethics and code of conduct. }\end{array}$ & $\begin{array}{l}\text { Ordinal Scale } \\
\text { Measured by } 5- \\
\text { point Likert scale }\end{array}$ \\
\hline $\mathbf{Y}$ & \multicolumn{3}{|c|}{ Variabel Independen } \\
\hline $\mathrm{Y}$ & $\begin{array}{l}\text { Accounting } \\
\text { Fraudulent } \\
\text { Tendency }\end{array}$ & $\begin{array}{l}\text { 1. recording revenue to soon } \\
\text { 2. recording bogus fictitious revenue } \\
\text { 3. boosting income with one time gains } \\
\text { 4. shifting current expense to a later of ealier period } \\
\text { 5. failing to disclouse liabilities } \\
\text { 6. shifting current income to a later period } \\
\text { 7. shifting future expense into the current periode }\end{array}$ & $\begin{array}{l}\text { Ordinal Scale } \\
\text { Measured by } 5- \\
\text { point Likert scale }\end{array}$ \\
\hline
\end{tabular}

\section{Analysis Method}

Analysis Method is based on the research objectives, the method of analysis used in this study are as follows:

1. Descriptive analysis

2. Conduct evaluation of measurement model (Outer model) by looking at the validity and reliability of variable indicator of latent contraction measure.
3. Structural Equation Modeling (SEM) Analysis

- Development of concept-based model and theory

- Construct Path Diagram for Structural Equation Model 


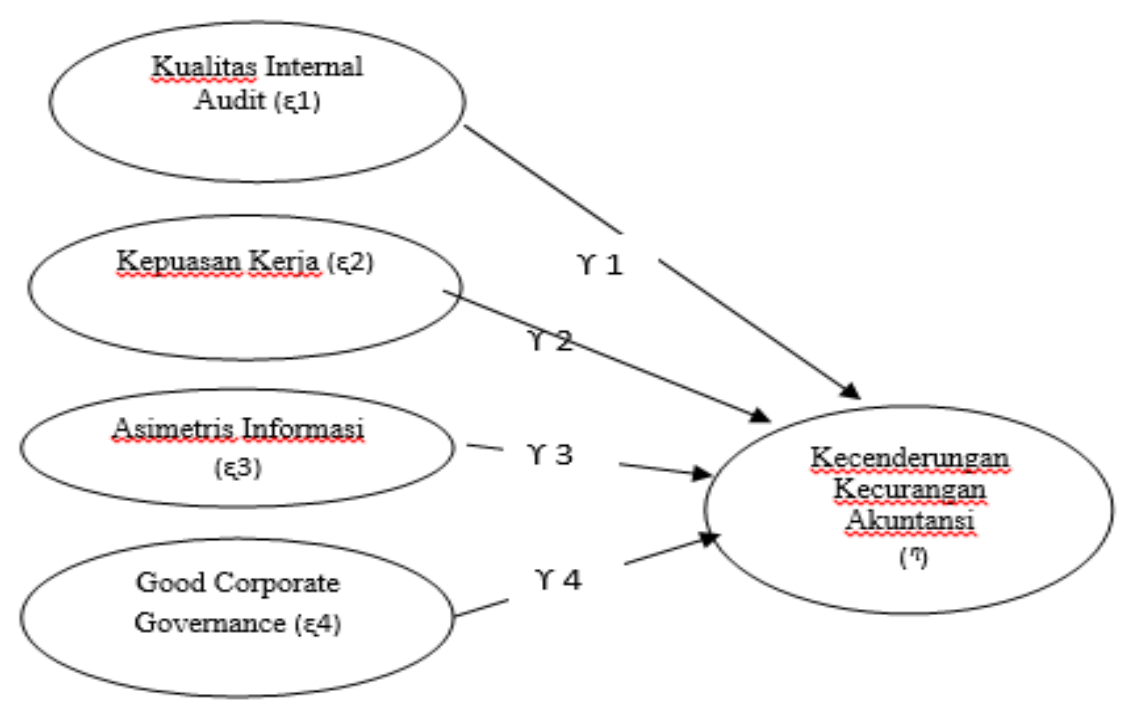

Image-1: Path Diagram of Accounting Fraudulent Tendency

a. Convert the path diagram into the equation. The path diagram in Image 1 is converted into the following equation:

Accounting Fraudulent Tendency $=\gamma 1$ Audit Internal Quality $+\gamma 2$ Job Satisfaction $+\gamma 3$ Asimetris Information $+\gamma 4$ Good Governance.

Estimate the model parameters and evaluate the model by looking at the percentage of variance which is described by looking at the value of R2.

a. Hypothesis testing. According to Dwi Pritano [18], hypothesis testing is a test to determine whether the conclusions on the sample can apply to the population (can be generalized). Hypothesis test is used to determine whether the proposed hypothesis is the correct statement / guess so that the hypothesis must be accepted or is a wrong statement / guess so that the hypothesis must be rejected.
The design of hypothesis testing in this study as follows:

$\mathbf{H}_{\mathbf{1}}$ : Internal Audit Quality influences Accounting Fraudulent Tendency

$\mathbf{H}_{2}$ : Job Satisfaction influences Accounting Fraudulent Tendency

$\mathbf{H}_{3:}$ Asymmetric Information influences Accounting Fraudulent Tendency

$\mathbf{H}_{\mathbf{4}}$ : Good Governance influences Accounting Fraudulent Tendency

\section{RESULTS AND DISCUSSION Descriptive Test Data}

Descriptive analysis of research variable data aims to describe research variables, without drawing generalizations. Frequency distribution of answers is basically to see the number of respondents who answer each alternative answer. From the results of the answers obtained, we can find out the answers that are generally chosen by the respondents.

\begin{tabular}{|r|r|r|r|r|r|}
\hline & Statistik Deskriptif \\
\hline & $\mathbf{N}$ & Minimum & Maximum & Mean & Std. deviation \\
\hline Audit Internal Quality & 88 & 10 & 50 & 39,48 & 6,92 \\
\hline Job Satsfaction & 88 & 10 & 50 & 38,81 & 7,08 \\
\hline Accounting Information System & 88 & 10 & 50 & 38,83 & 7,08 \\
\hline
\end{tabular}

Source: Excel Output Results, 2019

\section{Designing a Measurement Model (Outer Model)}

In conducting structural analysis of equation modeling it is necessary to evaluate the measurement model that defines how each indicator block relates to its latent variables using Confirmatory Factor Analysis (CFA) through testing validity and reliability on the data.

This stage is used to determine the validity and reliability that connects indicators with latent variables. The indicators in this study are reflective because indicators of latent variables influence the indicators for which 3 stages of measurement are used according to Latan and Ghozali [19].

\section{Discriminant Validity}

The evaluation is seeing square root of average variance extracted (AVE). The measurement model is assessed based on measurements of cross loading with the construct. If the construct correlation with each indicator is greater than the size of the other constructs, then the latent construct predicts the indicator is better than the other constructs. 
If the value of $\sqrt{A V E}$ is higher than the value of correlation between constructs, good discriminant validity is achieved. According to Latan and Ghozali [19] it is highly recommended if AVE is greater than 0.5. Following is the formula for calculating AVE:

$$
A V E=\frac{\sum \lambda_{\mathrm{i}}{ }^{2}}{\Sigma \lambda_{\mathrm{i}}{ }^{2}+\Sigma_{\mathrm{i}} \operatorname{var}\left(\varepsilon_{\mathrm{i}}\right)}
$$

Where is the factor $\lambda_{i}$ of loading (convergent validity), and $\operatorname{var}^{\prime}\left(\varepsilon_{\mathrm{i}}\right)=1-\lambda_{i}{ }^{2}$. Fornnel and Larcker in Latan and Ghozali [19] state that these measurements can be used to measure reliability and the results are more conservative than with the composite reliabity $(\rho c)$ value.

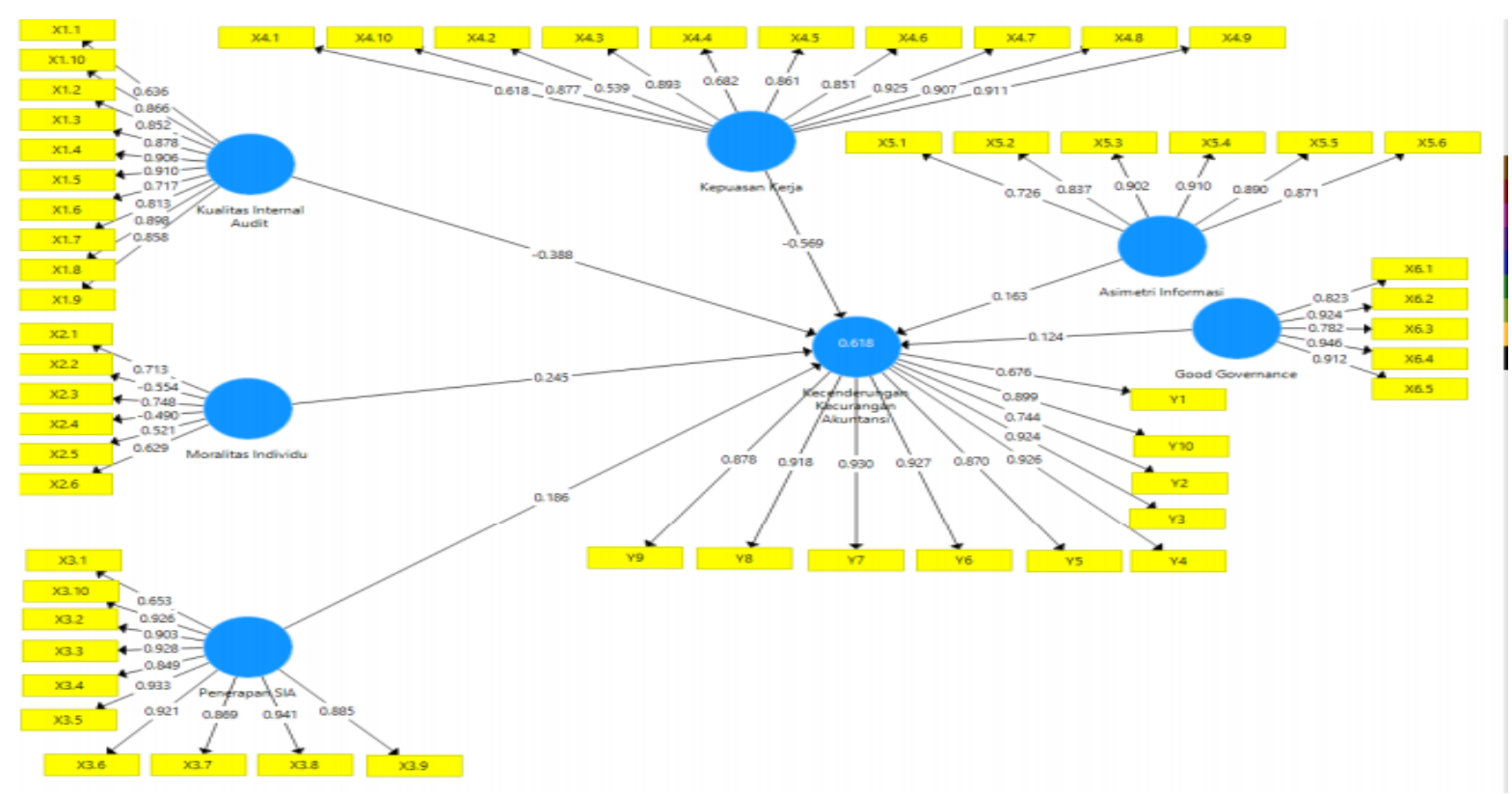

Image-2: Model processed by PLS3.0

Source: Data is processed by SmartPLS 3.0

Table-3: Discriminant Validity

\section{Construct Reliability and Validity}

\begin{tabular}{|c|c|c|c|c|c|c|c|c|c|}
\hline \multirow[t]{2}{*}{ 葍 } & \multirow[t]{2}{*}{ Matrix } & \multirow[t]{2}{*}{ 殒直 } & Cronbach's Alpha & 揕草 rho_A & \multicolumn{2}{|c|}{ 妭萻 Composite Reliability } & \multicolumn{2}{|c|}{ 拹落 Average Variance Extracted (AVE) } & \\
\hline & & & \multicolumn{2}{|c|}{ Cronbach's Alpha } & rho_A & \multicolumn{2}{|c|}{ Composite Reliability } & \multicolumn{2}{|c|}{ Average Variance Extracted (AVE) } \\
\hline \multicolumn{3}{|c|}{ ASIMETRIS INF... } & & 0.930 & 0.997 & & 0.944 & & 0.737 \\
\hline \multicolumn{3}{|c|}{ GOOD GOVER... } & & 0.927 & 0.968 & & 0.944 & & 0.774 \\
\hline \multicolumn{3}{|c|}{ KEPUASAN KE... } & & 0.942 & 0.961 & & 0.951 & & 0.668 \\
\hline \multicolumn{3}{|c|}{ KUALITAS INTE... } & & 0.951 & 0.959 & & 0.959 & & 0.702 \\
\hline \multicolumn{3}{|c|}{ TENDENCY AC... } & & 0.964 & 0.968 & & 0.969 & & 0.762 \\
\hline
\end{tabular}

According to the table above that the square root AVE Asymmetric Information is 0.737 , square root value AVE Good Governance is 0.774, AVE square root value Accounting Fraudulent tendency is 0.762, square root value AVE Job Satisfaction is 0.668 , square root value AVE Internal audit quality is 0.702 .

Table-4: Test Results of Average Variance Extracted (AVE)

\begin{tabular}{|c|c|}
\hline Variabel & Average Variance Extraced (AVE) \\
\hline KKA & 0,762 \\
\hline KIA & 0,702 \\
\hline KK & 0,668 \\
\hline AI & 0,737 \\
\hline GG & 0,774 \\
\hline
\end{tabular}

Source: Data is processed by SmartPLS 3.0
The AVE output shows that the AVE value is good for the constructs of Accounting Fraudulent Tendency (KKA), Internal Audit Quality (KIA), Job Satisfaction (KK), Asymmetric Information (AI), and Good Governance (GG) which have AVE values greater than 0.50 .

\section{Composite Reliability (CR)}

To determine composite reliability, if the value of $\rho c>0.8$ it can be said that the construct has high reliability or reliability and $\rho c>0.6$ is said to be quite reliable [19]. Here's the formula:

$$
\rho c=\frac{\left(\Sigma \lambda_{i}\right)^{2}}{\left(\Sigma \lambda_{i}\right)^{2}+\sum_{i} \operatorname{var}\left(\varepsilon_{i}\right)}
$$

Calculate the composite reliability $(\rho c)$ : 
Table-5: Result of Cronbach's Alpha and Composite Reliability

\section{Construct Reliability and Validity}

\begin{tabular}{|c|c|c|c|c|c|c|c|c|}
\hline \multirow[t]{2}{*}{ Matrix } & 捱草 & Cronbach's Alpha & 接直 rho_A & 拱直 Comp & liability & 拱真 Average & Extracted (AVE) & \\
\hline & & \multicolumn{2}{|c|}{ Cronbach's Alpha } & rho_A & \multicolumn{2}{|c|}{ Composite Reliability } & \multicolumn{2}{|c|}{ Average Variance Extracted (AVE) } \\
\hline \multicolumn{2}{|c|}{ ASIMETRIS INF... } & & 0.930 & 0.997 & & 0.944 & & 0.737 \\
\hline \multicolumn{2}{|c|}{ GOOD GOVER... } & & 0.927 & 0.968 & & 0.944 & & 0.774 \\
\hline \multicolumn{2}{|c|}{ KEPUASAN KE... } & & 0.942 & 0.961 & & 0.951 & & 0.668 \\
\hline \multicolumn{2}{|c|}{ KUALITAS INTE... } & & 0.951 & 0.959 & & 0.959 & & 0.702 \\
\hline \multicolumn{2}{|c|}{ TENDENCY AC... } & & 0.964 & 0.968 & & 0.969 & & 0.762 \\
\hline
\end{tabular}

Source: Data is processed by SmartPLS 3.0

The results of composite reliability output for constructs of Accounting Fraudulent Tendency (KKA) is 0,969, Internal Audit Quality (KIA) is 0,959, Job Satisfaction (KK) is 0,951 , Asymmetric Information (AI) is 0,930, and Good Governance (GG) is 0,944 . Composite Reliability $>0.80$ so it can be concluded that all construct indicators are reliable or in other words fulfill reliability tests.

\section{Cronbachs Alpha (CA)}

Reliability testing is reinforced by Cronbach alpha where the consistency of each answer is tested. If $\geq 0.5$ is good and if $\geq 0.3$ is enough.
Based on the calculation results, the Cronbach alpha value produced by all constructs is very good > 0.80 so it can be concluded that all reflective construct indicators are reliable or meet reliability testing. The results of cronbach alpha for constructs of Accounting Fraudulent Tendency (KKA) is 0,964, Internal Audit Quality (KIA) is 0,951, Job Satisfaction (KK) is 0,942 , Asymmetric Information (AI) is 0,930, and Good Governance (GG) is 0,927 .

However, according to Latan and Ghozali [19] Cronbach's alpha generated by Smart PLS is slightly under estimate so it is recommended to use Composite Reliability or Dillion-Goldstein's.

\section{Designing a Structural Model (Inner Model)}

Table-6: R Square

\section{R Square}

\begin{tabular}{|c|c|c|c|c|c|c|}
\hline \multirow[t]{2}{*}{ 葍 } & \multirow[t]{2}{*}{ Matrix } & & R Square & 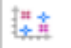 & R Square Adjusted & \multirow[b]{2}{*}{ R Šquare Adjusted } \\
\hline & & & & & R Square & \\
\hline \multicolumn{3}{|c|}{ TENDENCY AC... } & & & 0.564 & 0.543 \\
\hline
\end{tabular}

Source: Data is processed by SmartPLS 3.0

Table-6 shows the R-Square value variable of Accounting Fraudulent Tendency (KKA) is 0.564, in other words the influence model of Internal Audit Quality (KIA), Job Satisfaction (KK), Asymmetric Information (AI), and Good Governance (GG) to Accounting Fraudulent Tendency (KKA) gives the RSquare value of 0.564 . This means that $56.4 \%$ Accounting Fraudulent Tendency (KKA) variable can be explained by the variables of Internal Audit Quality (KIA), Job Satisfaction (KK), Asymmetric Information (AI), and Good Governance (GG) while $43.6 \%$ are explained by other variables outside of those research. From table 6 it can also be seen that the value of the RSquare Accounting Fraudulent Tendency (KKA) variable belongs to the moderate category because it is more than 0.5 but below 0.75 . 


\section{Construction Path}

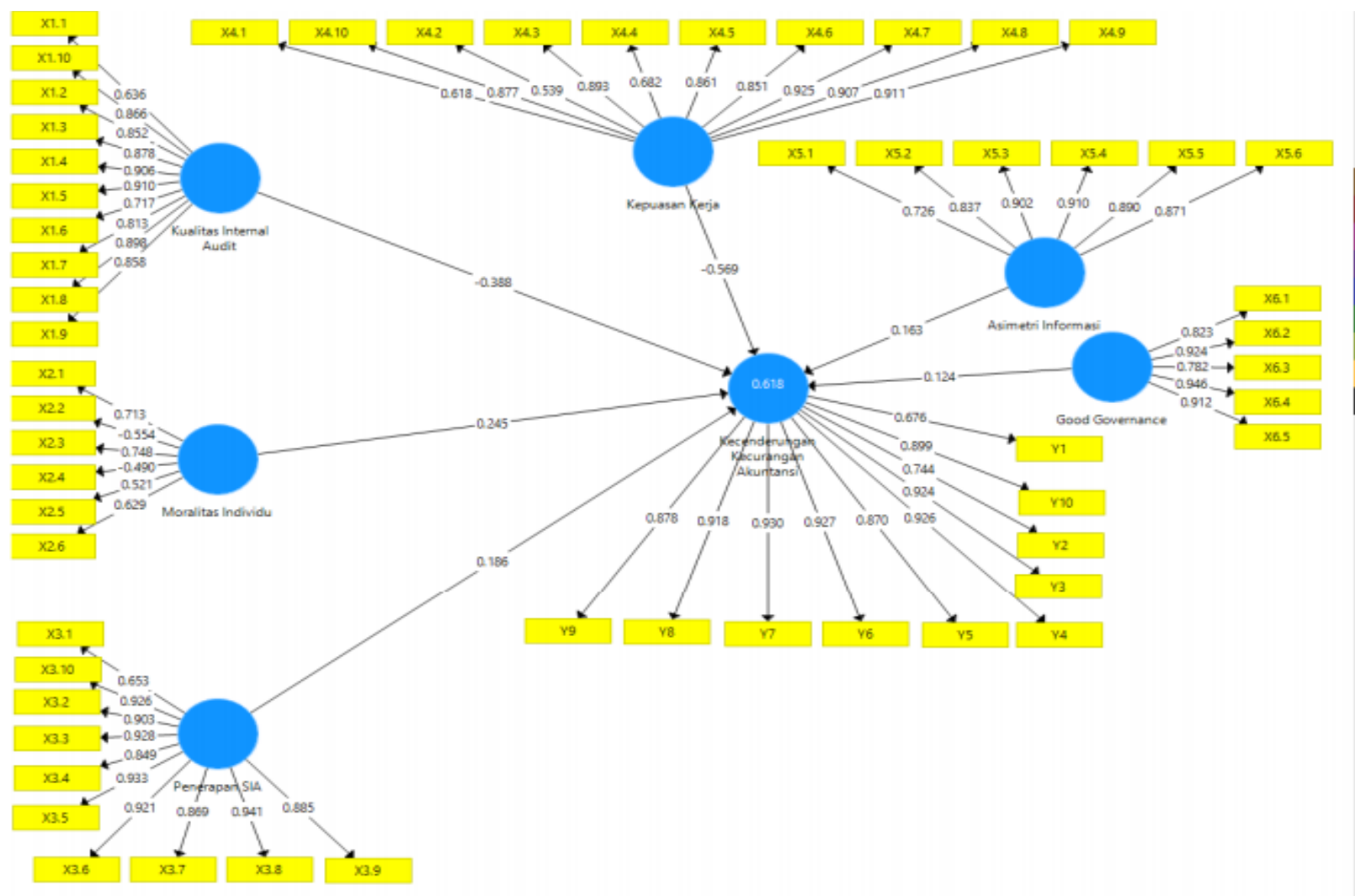

Image-3: The Construction of Line Diagram

Source: Data is processed by SmartPLS 3.0

\section{Resampling Bootstraping}

According to Latan and Ghozali [19], If the tstatistic value is smaller than the t-table value [t-statistic $<1.98]$, then Ho is accepted and Ha is rejected. If the tstatistic value is greater or equal to $\mathrm{t}$-table [ $\mathrm{t}$-statistics> 1.98], then Ho is rejected and Ha is accepted.

The hypothesis summarized in this study are:
$\mathbf{H}_{\mathbf{1}}$ : Internal Audit Quality influences Accounting Fraudulent Tendency

$\mathbf{H}_{2}$ : Job Satisfaction influences Accounting Fraudulent Tendency

$\mathbf{H}_{3}$ : Asymmetric Information influences Accounting Fraudulent Tendency

$\mathbf{H}_{\mathbf{4}}$ : Good Governance influences Accounting Fraudulent Tendency

Table-7: Path Coefficient Value Test Results

\section{Path Coefficients}

\begin{tabular}{|c|c|c|c|c|c|c|c|c|c|}
\hline \multirow[t]{2}{*}{ Mean, STDEV, T-Values, P-Values } & Confidence Intervals & \multicolumn{3}{|c|}{ (1) Confidence Intervals Bias Corrected } & \multicolumn{2}{|c|}{ Samples } & & & \multirow[b]{2}{*}{ P Values } \\
\hline & & & Original Sampl... & Sample Me & ean $(\ldots$ & - Standar & Devia... & T Statistics $(\mid 0 . .$. & \\
\hline \multicolumn{3}{|c|}{ ASIMETRIS INFORMASI -> TENDENCY ACCOUNTING FRAUDULENCE } & 0.163 & & 0.153 & & 0.110 & 1.477 & 0.140 \\
\hline \multicolumn{3}{|c|}{ GOOD GOVERNANCE -> TENDENCY ACCOUNTING FRAUDULENCE } & 0.040 & & 0.041 & & 0.084 & 0.468 & 0.640 \\
\hline \multicolumn{3}{|c|}{ KEPUASAN KERJA $>$ TENDENCY ACCOUNTING FRAUDULENCE } & -0.519 & & -0.536 & & 0.149 & 3.489 & 0.001 \\
\hline \multicolumn{3}{|c|}{ KUALITAS INTERNAL AUDIT $->$ TENDENCY ACCOUNTING FRAUDULENCE } & -0.353 & & -0.347 & & 0.125 & 2.827 & 0.005 \\
\hline
\end{tabular}

Source: Data is processed by SmartPLS 3.0

The effect of the relationship of exogenous latent variables on endogenous variables (Accounting Fraudulent Tendency) in Table-7 can be explained as follows:

1. The path parameter coefficient obtained from the relationship between the Internal Audit Quality variable and Accounting Fraudulent
Tendency is equal to -0.353 with a T-statistic value of $2.827>1.98$, then Ho is rejected and $\mathrm{Ha}$ is accepted. Internal Audit Quality Variable has a negative effect to Accounting Fraudulent Tendency.

2. The path parameter coefficient obtained from the relationship between Job Satisfaction 
variable and Accounting Fraudulent Tendency is equal to -0.519 with a T-statistic value of 3.489> 1.98, then Ho is rejected and $\mathrm{Ha}$ is accepted. Job Satisfaction variable has negative effect to Accounting Fraudulent Tendency.

3. The path parameter coefficient obtained from the relationship between Asymmetric Information variable and Accounting Fraudulent Tendency is equal to 0.163 with a T-statistic value of $1.477<1.98$, then $\mathrm{Ho}$ is accepted and $\mathrm{Ha}$ is rejected. Asymmetric Information variable has no effect to Accounting Fraudulent Tendency.

4. The path parameter coefficient obtained from the relationship between Good Governance variables and Accounting Fraudulent Tendency is equal to 0.040 with a T-statistic value of $0.468<1.98$, then $\mathrm{Ho}$ is accepted and $\mathrm{Ha}$ is rejected. Good governance variable has no effect to Accounting Fraudulent Tendency.

Based on the path parameter coefficients obtained in table 7 the structural equation models formed as follows:

Accounting Fraudulent Tendency $=0.163$ Asymmetric Information + 0.040 Good Governance 0.519 Job Satisfaction - 0,353 Internal Audit Quality.

\section{CONCLUSION}

The conclusions from this study indicate that:

1. A symmetric. Information variables has no effect to accounting fraudulent tendency.

2. Good Governance Variable has no effect to accounting fraudulent tendency.

3. Job Satisfaction Variable has a negative effect to accounting fraudulent tendency.

4. Internal Audit Quality Variable has a negative effect to accounting fraudulent tendency

\section{SUGGESTION}

Based on the results of the analysis and discussion that has been explained and the conclusions mentioned earlier, the authors provide suggestions that will be used as input and material considerations for interested parties as follows:

\section{For Companies}

The company's management still pays attention to job satisfaction and improves the quality of the internal audit of accounting, because thus hopefully increasing accounting adequacy.

\section{For Other Researchers}

- The variables used in this study are still limited, researchers suggest for further research to add variables that influence accounting fraudulent tendency.
- The population and samples used in this study are still limited compared to the number of branch offices and employees of banking companies in Tangerang. Future studies are expected to increase the number of populations and samples, so that the results of his research approach the actual conditions.

\section{REFERENCES}

1. https://www.transparency.org/whatwedo/publicati on/corruption_perceptions_index_2017

2. https://www.transparency.org/whatwedo/publicati on/corruption_perceptions_index_2016

3. Zainal, V. R., dan Muliaman, Darmansyah, H., \& Mansyur, R. (2014). Kepemimpinan dan Perilaku Organisasi. Edisi Keempat. Jakarta: PT. Raja Grafindo Persada.

4. Suginam, G. (2016). Pengaruh Peran Audit Internal Terhadap Pencegahan Fraud (Studi Kasus Pada PT. Tolan Tiga Indonesia). Medan: STMIK Budi Darma.

5. Abdi, S. (2017). Pengaruh Sistem Internal, Kontrol, Audit Internal dan Penerapan Good Corporate Governance Terhadap Kecurangan (FRAUD) perbangkan (Studi Kasus Pada Bank Syariah Anak Perusahaan BUMN di Medan), Medan: Politeknik Ganesha.

6. Parasmita, A. P. (2014). Pengaruh Keefektifan Pengendalian Internal dan Kepuasan Kerja terhadap Kecenderungan Kecurangan Akuntansi. Yogyakarta: UNY.

7. Kusumastuti, N. R., \& Meiranto, W. (2012). Analisis faktor-faktor yang berpengaruh terhadap kecenderungan kecurangan akuntansi dengan perilaku tidak etis sebagai variabel intervening (Doctoral dissertation, Fakultas Ekonomika dan Bisnis).

8. Jensen, M. C., \& Meckling, W. H. (1976). The theory of the firm: Manajerial Behaviour, Agency cost and ownership Structure'. Journal of Financial and Economics 3;305-360.

9. Karyono. (2013). Forensic Fraud. Yogakarta: CV. Andi Offset.

10. Sukrisno, A. (2017). Auditing: Petunjuk Praktis Pemeriksaan Akuntan oleh Akuntan Publik. Jakarta: Salemba Empat.

11. Mappanyukki, R. (2010). Pengaruh Penerapan Pengendalian Internal Terhadap Pencegahan Eraud Pengadaan Barang Dan Implikasinya Pada Kinerja Keuangan (Studi Pada Rumah Sakit Pemerintah Dan Swasta Jakarta).

12. Hidayat, A. A., Kholil, M., \& Hasbullah. (2017). Manajemen Sumber Daya Manusia untuk Organisasi yang Lebih Kreatif dan Berdaya Saing Tinggi. Yogyakarta: Wahana Resolusi.

13. Surjandari, D. A. (2015). An Empirical Study: The Effect of Performance Incentives, Internal Control System, Organizational Culture, on Fraud of Indonesia Government Officer. 
14. Wilopo, S. A. (2006). Perkembangan Teknologi Kontrasepsi Pria Terkini. Gema Pria. Available from: http://pikas. bkkbn. go. id/gemapria/articledetail php. Accesed.

15. Saftarini, P. R., Yuniarta, G. A., AK, S., \& Sinarwati, N. K. (2015). Pengaruh Efektivitas Pengendalian Internal, Asimetri Informasi dan Implementasi Good Governance terhadap Kecenderungan Kecurangan (Fraud) Akuntansi (Studi Empiris pada SKPD Kabupaten Bangli). JIMAT (Jurnal Ilmiah Mahasiswa Akuntansi) Undiksha, 3(1).
16. Petruccelli Jr, D. (2007). U.S. Patent Application No. 29/256,

17. Ghozali, I. Fuad. (2005). Structural equation modeling: teori, konsep, dan aplikasi dengan Program Lisrel, 8, 1-17.

18. Simorangkir, R. T. M. C., \& Kurniawati, E. (2010). as Moderation Variable.

19. Latan, H., \& Ghozali, I. (2012). Partial Least Square: Konsep, Teknik, dan Aplikasi SmartPLS 2.0 M3. Semarang: Badan Penerbit Universitas Diponogero.

20. Supranto, J. (2007). Statistik untuk pemimpin berwawasan global. Salembaempat: Jakarta. 